\title{
Design of Production Performance Improvement System of Aromatic Chemical Industry
}

\author{
Efendi ${ }^{1}$, Anas Miftah Fauzi ${ }^{1}$, Machfud $^{1} \&$ Sukardi $^{1}$ \\ ${ }^{1}$ Bogor Agricultural University, Indonesia \\ Correspondence: Efendi, Bogor Agricultural University, Indonesia. E-mail:efenditoha@yahoo.co.id
}

Received: January 2, 2014

Accepted: February 24, $2014 \quad$ Online Published: March 21, 2014

doi:10.5539/ijbm.v9n4p140

URL: http://dx.doi.org/10.5539/ijbm.v9n4p140

\begin{abstract}
Competitiveness of Indonesian essential oil industry is still low due to inefficiency in the production and uncertainty in the availability. Lean production system is reported to have the capability to improve efficiency through lowering cost, reducing lead time (faster delivery) and higher quality. The purpose of this reasearch is to design production performance improvement system in the aromatic chemical industry, using modified Rother and Shook's value stream mapping (VSM) model for aromatic chemical industry. Aromatic chemicals of clove leaf oil derivative were used in this research. Critical observation was used to understand the processes involved in the value stream. Current state of the selected clove leaf oil derivatives, Eugenol and Isoeugenol, were prepared using VSM and improvement areas were identified. A few modifications in the current state and, with these modifications, a future state map is suggested. After comparing the current state and future state map, it has been found that there was $64 \%$ reduction in the production lead time of Eugenol and $72 \%$ reduction in the production lead time of Isoeugenol. In this research VSM was also succesfully used to identify production losses in the value stream. The research shows that VSM can be used to design production performance improvement system of aromatic chemical industry. Production performance of aromatic chemical industry can be improved by implementing lean production system.
\end{abstract}

Keywords: lean production system, value stream mapping, efficiency, lead time

\section{Introduction}

Competitiveness of essential oil industry in Indonesia is low, and it is reflected by the lower productivity due to inefficiency in the production and uncertainty in the availability (Indonesian Ministry of Industry, 2009). In the essential oil industry, especially in the aromatic chemical industry, efficiency efforts can be focused on the handling of raw material. It is because raw material components in the cost of goods manufactured of aromatic chemical is between $80-98 \%$ of total cost of goods manufactured.

Raw material cost is determined by the price of raw material, production losses and production lead time. In the long run, strategy which can be used as a competitive advantage of aromatic chemical company is doing efficiency to shorter lead time and minimize production losses.One of production system that has an aim to have lower production cost, shorter production lead time and higher quality is lean production system.

Abdulmalek, Rajgopal and Needy (2006) found that from various lean techniques, value stream mapping (VSM) is the most important, which can be used for various manufacturing industries and give the best starting point for wastes identification and redundancy. Hines and Rich (1997) identified that in general there are 7 wastes in the production activities: over production, waiting, transport, inappropriate processing, unnecessary inventory, unnecessary motion and defects. In the production context, there are three operation: non-value adding activities, necessary but non-value adding activities and value adding activtites. A non-value adding activities is a pure waste, it involves unnnecessary activities and can be eliminated.

D. Seth, N. Seth and Goel (2008) concluded that one of the best tool to reduce production lossess and production lead time is value stream mapping. Value stream mapping started from automotive industy, and have been applied much in the similar industry (discrete industry). Application of value stream mapping in processing industry, especially in aromatic chemical industry have not been done yet. Because of value stream mapping have been started and applied much in automotive industry, therefore to be used in aromatic chemical industry need to be modified for some adjusment. One of concept that need to be adjusted is takt time. The way to collect 
information of material flow also need to be modified. Value stream mapping focuss only in the inventory at each activities, while in aromatic chemical industry, because raw material components in the cost of goods manufactured is very significant, beside inventory, production losses at each activities also need to be addressed.

Rathi and Farris (2010) discussed that in the last three decade, discrete manufacturing industry all over the world have applied lean priciples and techniques to get success improvement in their production system. However application of lean approach in the process industry is slower than in dicsrete industry, because of specific characteristic of process industry. The slownessof lean application in the processs industry due to process inflexibility, unfeasible small lot size, demand cycle, storage cost, transportation and change over. Application of lean priciples and techniques in the process industry needs different approach and potentially more challenging compared to discrete manufacturing. In the other hand, research about lean application in the process industry is still limited.

Several research of value stream mapping application in various industry are B. Shing and Sharma (2009) in the automotive components; Lasa, Laburu and Vila (2008) in the plastic cassing of cellular phone;Shen and Han (2006) in the electrical manufacturing services (EMS); Coronado, Adrian and Andrew (2007) in the shower industry; B. Singh, Garg and Sharma (2010) in the diesel traction feet component industry; Wee and Wu (2009) in the automotive; Guiterrez, Barajas, Galaviz and Martinez (2003) inthe logistics industry; Woll (2003) in the teaching technology industry; D. Seth et al. (2008) in the cotton seed oil industry; H. Singh and A. Singh (2013) in the auto-parts industry.

Based on several research about application of value stream mapping above can be seen that much value stream mapping application research is in the discrete manufacturing industry, as discussed by Rathi and Farris (2010), and only one research is in the processing industry that is in the cotton seed oil industry. Previous researchs above conclude that value stream mapping tool can be used to redesign production system to improve production performance which is to reduce production lead time, inventory, production cost and man power.

Based on the explanation above, it is necessary to do research to know how value stream mapping can be applied in the aromatic chemical industry, which is one of processing industry, to strenghten value stream mapping concept and also to develop its application. It will also give contribution to the development of aromatic chemical industry. The purposes of this reasearch is to design production performance improvement system of aromatic chemical industry based on value stream mapping. This study looks to answer the research questions: (1) How can the value stream mapping commonly used in the discrete industry be adjusted for use in aromatic chemical industry? (2)How can the value stream mapping be used to identify value-adding and non value-adding activities in aromatic chemical industry? (3) How can the value stream mapping be used to improve production performance in aromatic chemical industry?

\section{Literature Review}

\subsection{Lean Production}

Lander (2007) discussed that lean production has become a leading paradigm in the manufacturing and there are many companies in the world adopt this principles. However, most of succesfull story of lean implementation come from Toyota group or companies with similar condition, such as limited variation, high volume production, predictable demand. To implement lean succesfully in other industries, lean should be considered as a way of thingking or philosophy, not as just a tools or system. As a philosophy, lean is a production philosophy to shorter time between customer order up to delivery by minimizing waste or unnecessary activities.

Alves, Carvalho and Sousa (2012) explored lean production paradigm as a driver of creativity and thinking potential of employee and acknowledge this potential as an asset for company success. The research shows that there is a correlation between lean production and impulse to think. Lean production is a working organization model which employee takes a role as a thinker, seeking waste and improvement continuously. Company will be more ready to accommodate change and get agility by reducing waste. Yamamoto and Bellgran (2010) in their research found that in the lean implementation, it is better to focus on creating need for improvement instead of planning in detail steps for implementation. Lean techniques are used only to solve problem.

Correlation between lean production and sustainable competitive advantage was researched by Lewis (2000). It found that lean production will support competitive advantage if companies can take benefit from a created productivity saving. Implementation process of lean production can create strategic resources to support sustainable competitive advantage of the companies. Chauhan and P. Singh (2012) tried to identify and measure parameters strongly related to lean production and examine its contribution to overall lean production. It concluded that waste reduction is the most important in the lean production, followed by just in time delivery. 
Upadhye, Deshmukh and S. Garg (2010) investigated the importance of lean production to get sustainable improvement of organization. Key to achieve sustainable improvement is customer satisfaction through better quality, lower cost, faster delivery and good communication. Lean production helps to identify and eliminate waste at every step of operation systematically. This research found an indication that systematic approach integrating all functions in the organization to identify and eliminate waste help organization to have better performance. Rahman, Laosirihongthong and Sohal (2010) examined impact of lean management practices to operation performance. It used just in time, waste minimization and flow management as lean management practices. Delivery time compared to competitor, cost of goods manufactured compared to competitor, and productivity and customer satisfaction are used as operation performance. It found that those three lean management practices have significant impact to operation performance.

Miina, Saat and Kolbre (2013) in their research tried to develop a model of implementation process of lean thinking, which can be used by manufacturing companies to get successful result from implementation oflean production. The research shows that in general lean thinking should be included in the company language as a part of production system of the company. Bhasin (2012) explored importance of appropriate change strategy to get successful in the lean implementation. The research shows the importance of a change, successful lean implementation needs systematic and controlled change strategy. Characteristics of successful lean implementation need a high commitment employee. Angelis, Conti, Cooper and Gill (2011) examined relation of employee commitment and lean production. It concluded that employee commitment is needed in the implementation of lean production. It is necessary to build a system that boost employee commitment. Keogh (2006) in his research on factors contributing to lean production success concluded the importance of awarness of participants in the lean production.

Sun (2011) discussed that lean production is the third milestone in the industrialization history. The key is to eliminate waste at all company activities through building production system that has high agility. Lean production has been considered as a standard production management approach in the 21 century. Ben-Tovim et al. (2007) concluded that lean thinking is a method to organize complex production process to encourage flow and reduce waste. Vinodh, Arvind and Somanaathan (2011) discussed that lean production is a production system that is focused in the waste elimination, thus facilitate streamlining process and waste reduction.

Forrester, Shimizu, Soriano-Meier, Garza-Reyes and Basso (2010) discussed that resource-based view consider main operation and organization advantage is made internally in the company. Implementation of lean production describes potential of strategic advantage to competitor. Forrester et al. tried to investigate relation between implementation of lean production and market share and company value creation in the Brazil agriculture machinery company. It found that companies in the sector that support a transition for implementation of lean production shows significant improvement in their business performance. Simons and Keivan (2005) concludes that lean is an established industry paradigm and has a proven significant benefit to different sectors in the manufacturing industry. Shah (2002) concluded that lean production practices give benefit in cost and flexibility in the operational level that will boost company responsiveness. Olsen (2004) discussed that lean production is related to better cash-to-cash cycle.

Lean production has been used widely in the automotive industry and has been expanded the implementation in the other discrete production, especially in the assembly process type. As an example including electronic, appliance household and consumable goods. In the other hand, implementation in the process industry is much slower. The slow adoption of lean in the process industry is beacuse inflexibility of process industry and difficulty related to small size production, which is main philosophy of lean. The main purposes of lean production is cost reduction, quality improvement and faster delivery through waste elimination and amployee empowerment. Lean focusses on elimination or reduction of waste and on maximizing or optimizing value-adding activities (Abdulmalek et al., 2006).

Success story in the lean production has been widely associated with automotive industry and other discrete production, especially assembly process type, in which lean techniques has been used widely. The chalenge is to faster the implementation in the process sector. Environment of process production is often characterized by high volume, low product variation and inflexible process. It will be difficult to produce in small lot in the process industry, because set up time is very long and the cost to stop process for product change over is very expensive. However, beacuse potential benefit of lean implementation is very promising, it needs to be tried to implement with some modification according to process indutry characteristics. 


\subsection{Value Stream Mapping}

One of tools that can be used to do efficiency is value stream mapping. The purpose of value stream mapping is to eliminate or reduce non value-adding activites or usually called waste or muda. There are tools that are developed to do efficiency by identification and eliminate waste, that are: (1) The seven value stream mapping tools (Hines \& Rich, 1997), (2) Value stream analysis tool (Hines, Rich, \& Hittmeyer, 1998), (3) Value stream mapping (Rother \& Shook, 2003). The seven value stream mapping tools consist of 7 tools, if it used simultaneously will give effective framework in the identification and elimination of waste. Value stream analysis tool (Valsat) can help to improve knowledge in the value stream. McManus and Millard (2002) discussed that value stream mapping of a process gives an overview from a real system that is very complex into two dimension format that less complicated.

Value Stream Mappingis one of many tools, working methods and concept in the lean environment. Other tools are including just in time (JIT), Single Minute Exchange of Die (SMED), 5S and Kanban. Value Stream Mappingcan be used in the all production type and can be studied easily and be implemented by everybody (Solding \& Gullander, 2009). Value Stream Mapping is a very valuable tool in the lean production and in the sustainable improvement efforts (Donatelli \& Harris, 2001).

Value stream mappingcan be used to map all value-adding activites in the company, from raw material up to finished goods that is ready for delivery to customer. Value stream mappingcan be used also to identify waste in the company. Production process to convert raw material into finished goods through a process series, which sometimes unnecessary or non value-adding, but because it was done many years become a common practices. The non value-adding activities will burden company because it will just add company cost. Value stream mapping will identify non value-adding activites and can be eliminated or reduced. It will improve company performance. Watson (2006) concluded that lean production principles and techniques has significantly improved organization performance. Fullerton and Wempe (2009) found that the use of non financial measures can mediate relation between lean production and financial performance.

Value stream mappingis a valuable tool to redesign production system based on lean principles (Lasa et al., 2008). Based on several researchs, it is concluded that value stream mapping can reduce cost, inventory and production lead time. Wee and $\mathrm{Wu}(2009)$ found that implementation of value stream mapping help reduce cost, increase quality and reduce lead time, while D. Seth et al. (2008) found that there was over stock equal to 244 days in the overall supply chain in the cotton seed oil industry in India. Brosnahan (2008) concluded that inventory can be reduce up to $30 \%$ by lean implementation.

Related to reduction of production lead time, B. Singh and Sharma (2009) found that implementation of value stream mapping reduce production lead time $92.38 \%$, reduce processing time $2.17 \%$, reduce works in process $97.1 \%$, reduce human resources $26.08 \%$. Singh et al. (2010) found that implementation of value stream mapping reduce production lead time $83.14 \%$, reduce processing time $12.62 \%$, reduce works in process $89.47 \%$, and reduce human resources 30\%. Woehrle and Abou-Shady (2010) discussed that simulation can be considered as an integral part of value stream mapping and can be used as a visual tool to convince management to adopt lean.

Woll (2003) in his disertation tried to implement value stream mapping in the teaching technology. His framework is that value stream mapping is a tool that can be used to reduce cycle time and improve production process. This tool introduce standardization in the production process that give foundation for continous improvement activities, enable employee to contribute in the improvement of production system. Woll realize that it will need some modification in order to implement value stream mapping in the teaching technology. Chen and Meng (2010) discussed that many compnies in the mainland China that has implemented lean production considering many succesfull implementation in other countires, however many of the companies fail to realize their first target because they started implementation of lean production from tool level and have not understood actual value stream of its business.

Shen and Han (2006) examined implementation of VSM in the Electrical Manufacturing Services industry in China. Production lead time (PLT) and value-added lead time (VASLT) are used to investigate the difference before and after VSM implementation. It found that there is an improvement between before and after VSM implementation. PLT improves $81 \%$ and VALT improves $10 \%$. Guiterrez et al. (2003) investigated implementation of VSM in logistics industry to improve logistics system in the company by identification existing problem in the transportation and inventory using lean production principles. It found that the most important improvement is in the raw material inventory, there was inventory reduction from 4 days to 1 day. In the transportation, there was reduction in the waiting time for truck from 3 days to 1 day. There was significant reduction for total time in the factory from 13 days to 9 days. 
Gahagan (2007) developed VSM template in the Arean software. Drawing VSM by hand is not always an effective communication. Map sometimes needs to be changed into power point for presentation to ask approval, which is this is a non value-adding process. VSM template in Arena enable user to create map in Arena, that can be put in the presentation and also can be use for simulation. This model can be used to validate and change a map. Coronado et al. (2007) used VSM to draw all activities (value-adding and non value-adding activities) needed to make a product from raw material to customer. VSM was used to identify waste and the root cause. It found that VSM is an effective tool that can be used to measure supply chain performance through identification of inefficiency related to design or supply chain integration. Practical implication of their research is that production industry needs tool that can be used in the production operation and supply chain analysis to improve performance.

H. Singh and A. Singh (2013) investigated implementation of lean production using VSM concept in the auto-parts manufacturing company. VSM concept is used to draw current-state map and future-state map in the production to identify sources of waste to improve competitiveness. It found that by comparing current-state map and future-state map, there was reduction in the cycle time $69.41 \%$, reduction in the works in process $18.26 \%$ and readuction in the production lead time $24.56 \%$ for Replacement ball product, while for Weldon ball there was reduction in the cycle time $51.87 \%$, reduction in the works in process $21.51 \%$ and reduction in the production lead time $25.88 \%$.

\section{Research Method}

This research was done in one of aromatic chemical company in Indonesia, on January 2012-May 2013. Data collection was done by observation all activities for producing aromatic chemicals in the company. This research usedpurposive sampling. Design of production performance improvement system was done using value stream mapping tools of Rother and Shook (2003), which were: (1) select a product family, (2) find value stream manager, (3) draw current-state map, (4) draw future-state map. Product family that was used in this research was aromatic chemicals derivative of clove leaf oil, Eugenol and Isoeugenol, which are main products of the company. Current-state map was analyzed to identity waste through anlalyzing customer demand, material flow and information flow. Waste was analyzed using waste categorization proposed by Hines and Rich (1997).

In this research, processing time and production lead time were calculated. Processing time is time that is needed to do production process, that is time that have value added to the product, while production lead time is total time that is needed to change raw material into product that ready to be shipped to customer. Production lead timeconsists of time that have value added to the product (processing time) and also time that do not have value added to the product. Calculation of processing time and production lead time were done in the current-state map, which is current condition before redesigning of production system. Evaluation was done to current state map, to see what activities contribute to production lead time but do not give value added to the product, and then redesign to reduce or eliminate non value added activities.

Result from current-state map evaluation then was drawn in the future-state map to get new design of production system that more efficient, that is non value added activities are reduced or eliminated. Processing time and production lead timeof the new production system were calculated in the future-state map to know how much improvement of production performance is got. Total production lead timewas calculated according to method of Rother and Shook (2003), that is add lead time (in time unit) for every inventories between production process activities, added by lead time needed in the each production process activities.

In this research, VSM was developed to analyze also production losses that exist in every step of production. Production losses are defined a negative quantity difference of product after production activities. It was calculated by comparing the quantity of product before and after production. Production losses were also calculated in every production process activities in value stream to know which activates has the biggest losses that need to be addressed for improvement.

\section{Results and Discussion}

The aromatic chemical company that is used in the research has 2 plants in Indonesia, which is in Central Java and West Java. Research was done in the two plants, which at every plant taken one main product in the plant as a model that is Eugenol in the Central Java plant and Isoeugenol in the West Java plant. Data lead time and production losses for production process of Eugenol are taken from 30 batches. VSM production process of Eugenol current-state is shown in Figure 1.

VSM current-stateproduction process of Eugenol starting from raw material is consumed for production process up to product delivered to warehouse shows that production lead time is 813.8 hours (33.9 days), while 
processing time is only 123.9 hours (5.2 days). It shows that value added time, reflected by processing time, is just $15 \%$ of production lead time $.85 \%$ of non value added activities come from inventory of raw material in the production, inventory between isolation and separation 1 process, inventory between separation 1 and blending process, inventory between blending process and good receive process in the warehouse. These inventories can be reduced by implementation of pull system in the activities that is possible to be implemented pull system and implementation of small size lot.

VSM Rother and Shook can be used also to analyze production losses, that is by identification production losses at every step of production process. Production losses analysis using VSM Rother and Shook is new implementation of VSM Rother and Shook as in the original VSM this analysis is not included. Data shows that the biggest production losses in the Eugenol production is in the separation step that is average $4.2 \%$. It means separation step contribute $91 \%$ of total losses of Eugenol production. Based on the Pareto principle, by addressing production losses on the separation process will reduce significantly total production losses of Eugenol production.

Based on the analysis of VSM current-state on Figure 1, can be designed production performance improvement system, as shown in VSM future-state Figure 2. It confirms Lasa et al. (2008) conclusion that VSM is very important analysis tool to redesign production system based on lean system. VSM future-statesshows total production leads timebecome 291.9 hours and processing timethe same at 123.9 hours. It means that total production lead time has decrease from 813.8 hours (33.9 days) become 291.9 hours (12.2 days) or decrease $64 \%$.

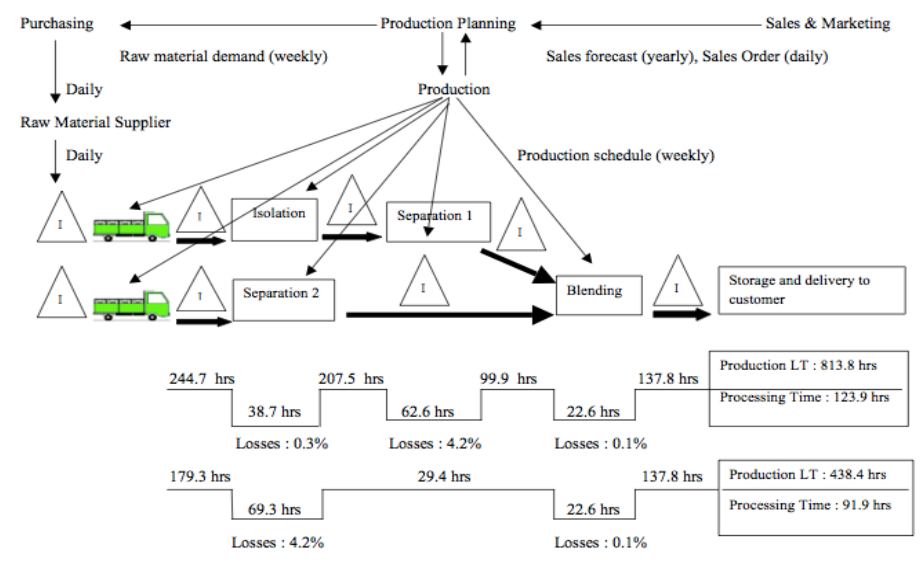

Figure 1. Value stream mapping of Eugenol production-current state

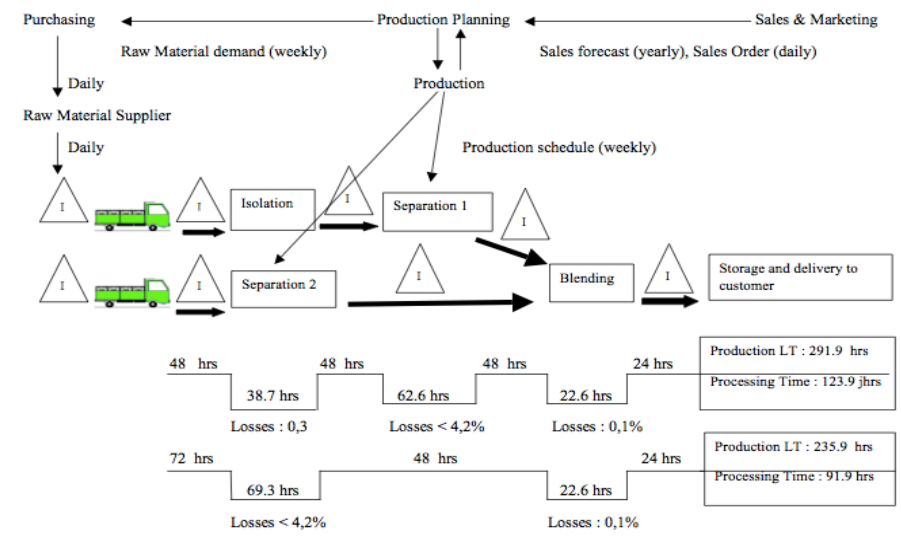

Figure 2. Value stream mapping of Eugenol production-future state

In the Eugenol production, several wastes or non-value adding activities are over production, waiting, transportation, unnecessary inventory and defect. Over production exist because of push production system, so 
quantity of production is not drived by demand in the next process, but it is determined independently (push). Waiting activities and also unnecessary inventory are also related to push system. Therefore, push system has cause three non-value adding activities that are over production, waiting and unnecessary inventories. By changing push system with pull system, will eliminate this three non-value adding activates.

Transportation in the Eugenol production is non-value adding activities; however it is still needed considering the company has separate location for warehouse, isolation process and separation process. Therefore, eventhough transportation is non-value adding activates in the Eugenol production; it is still needed in the existing condition of the company. Other non-value adding activates in the Eugenol production is activities related to product defect. Product defect will definitely consume resources to rectify it, such as time, manpower, equipments and materials. Production process standardization and training to improve competency of production personnel are needed to minimize product defect.

Analysis of VSM current-state of Isoeugenol production, the same as analysis of Eugenol production, was collected from 30 batches production process. Result of the VSM Current-state analysis is shown in the Figure 3. Based on the VSM current-state of Isoeugenol production, starting from raw material is consumed until product delivered to warehouse; total production lead time of Isoeugenol production is 764.5 hours (31.9 days), while total processing time is just 120.6 hours (5.0 days). It shows that in the production of Isoeugenol value adding activities are just $16 \%$, and the rest $84 \%$ is non-value adding activities. The non-value adding activities in the Isoeugenol production are raw material inventory in the production before reaction process, inventory between reaction and separation process, inventory between separation and blending process, inventory between process blending and reservation of product in warehouse. These inventories can be reduced by implementation of pull system in every production activities that possible for pull system implementation, implementation of continuous system and implementation of small lot size.

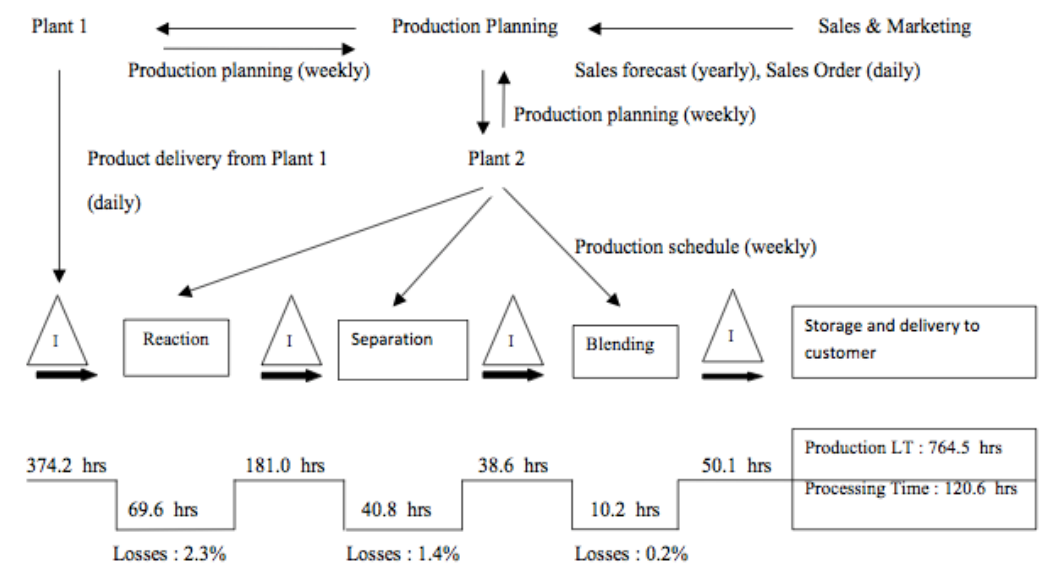

Figure 3. Value stream mapping of Isoeugenol production-current state

Based on the analysis of VSM current-state for Isoeugenol production on Figure 3, can be designed production performance improvement system for Isoeugenol production as shown in the VSM future-state of Isoeugenol production, Figure 4. Total production lead time in the VSM future-state become 216.6 hours (9.0 days) and processing time is still the same at 120.6 hours (5.0 days). It means that total production lead time has decrease $72 \%$, from 764.5 hours (31.9 days) become 216.6 hours (9.0 days). VSM future-state of Isoeugenol production shows that performance of Isoeugenol production can be improved by implementation of pull system,continues system and small lot size. Identification of production losses in the Isoegenol production also shows process activities need to be addressed to minimize total production losses because the process has the biggest production losses, which are reaction and separation process.

In the Isouegenol production, some wastes or non-value adding activates are over production, waiting, transport, not necessary inventory and product defect. Same as in the Eugenol production, over production exist because of push system that was implemented in the existing production system. Waiting activities and also not necessary inventory also related with the implementation of the existing push system. These three wastes can be reduced by implementation of pull system instead of push system. 


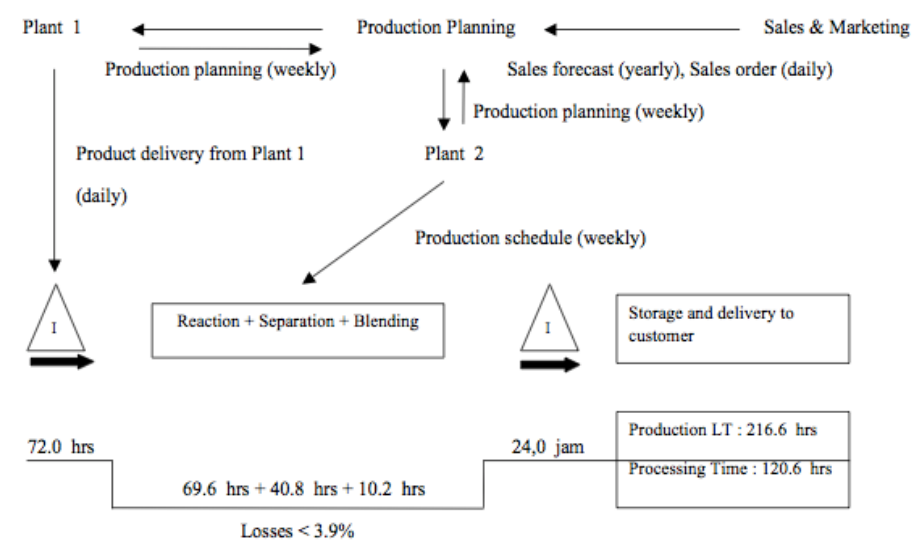

Figure 4. Value stream mapping of Isoeugenol production-future state

Transport activities in the Isoeugenol production is non-value adding activites, however it is still needed in the existing set up of the plants, considering that raw material for Isoeugenol production is sent from the first plant that the location is separated from the second plant. Implementation of continuous production system in the reaction and separation process and also implementation of small lot size in the Isoeugenol production will eliminate or at leat least reduce three non-value adding activities that are not necessary inventory, over production and waiting, the same as implementation of pull system. Implementation of continuous process of reaction and separation process will eliminate inventory between reaction and separation process and also eliminate over production. Implementation of small lot size will eliminate waiting activities because product can be blended every batch without waiting the second batch, so one batch process is one lot product.

Other non-value adding activates in the Isoeugenol production is activities related to product defect, the same as in the Eugenol production. Product defect will definitely need resources to rectify the product and it should be not necessary when there is no product defect. Product defect can be minimized by standardization of process and increase competency of production personnel by more training.

Based on the research that has been done to improve production performance in the aromatic chemical industry, in this case is used aromatic chemical derivative of clove leaf oil as a model, it can be designed production performance improvement system of aromatic chemical industry as shown in the Figure 5. Improvement of aromatic chemical industry performance can be done through implementation of lean production thatis pull system, continuous system and small size lot.

Aromatic chemical company needs to have enough raw material inventories to be able toimplement lean production. It can be done by synchronizing of raw material buying with availability of the raw material. When availability of raw material is abundant, aromatic chemical company is suggested to buy the raw material as much as possible, follow the supply, and when the supply of raw material is limited, it is suggested not to insist to buy. It is because the raw material of aromatic chemical industry is essential oil, which the supply depends on the climate.

Aromatic chemical company also needs to have safety stock of product to be able to implement pull system. This safety stock of product is dynamic, that is following the demand of the product. Monitoring safety stock of product compared to customer order daily is very important for production planning. Production planning is scheduled weekly based on the evaluation of safety stock and customer order. However, if there is a situation where customers order for certain product is increasing, by daily monitoring of customer order, production scheduled can be adjusted based on the customer order. 


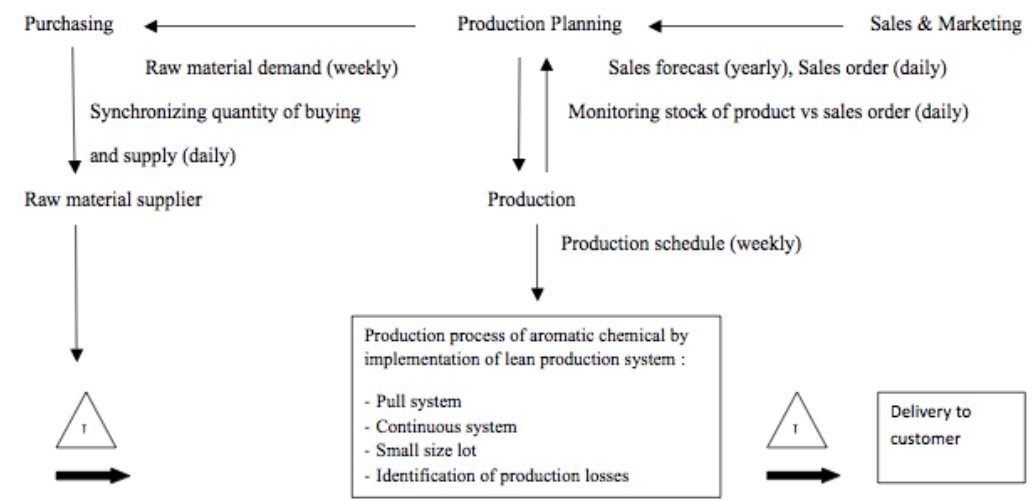

Figure 5. Design of production performance improvement system of aromatic chemical industry

\section{Conclusion}

This research shows that VSM can be used to design production performance improvement system in the aromatic chemical industry. Performance of aromatic chemical production, with Eugenol and Isoeugenol are used as a model in the design, can be improved respectively by $64 \%$ dan $72 \%$, by reduction in their production lead time. Design of production performance improvement system of aromatic chemical industry is done through implementation of lean production system, that are pull system in the activities that is possible to implement pull system, implementation of continuous system in the activities that is possible to implement continuous system, and implementation of small lot size to increase speed and flexibility in the production.

This research also shows that VSM can be used to identify at which activities has the biggest production losses, so efficiency effort to minimize product losses can be focused in those activities. This is a new development of VSM application. Minimizing productionlossescan increase production performance, especially in the aromatic chemical industry where raw material cost is very significant in the cost of goods manufactured.

Reduction of production lead time and minimizing production losses will improve performance of aromatic chemical industry significantly. It will serve customer better and will reduce cost of goods manufactured. VSM application in the aromatic chemical industry could be done continuously step by step, to do continuous improvement by drawing and comparing current-state map and future-state map. Future-state map will become a new foundation to do continuous improvement for the next step.

The successful implementation of VSM in the aromatic chemical industry will add more references of VSM application in the process industry. New implementation of VSM to identify production losses in the aromatic chemical industry will also contribute to a new application of VSM in the process industry. This new implementation will boost VSM concept and will make VSM concept more established not only in the discrete industry but also in the process industry.

More research of VSM implementation in the aromatic chemical industry using different aromatic chemical derivative other than clove leaf oil is needed to make the conclusion more assertive. More research also needs to be done to implement VSM in more process industry to establish VSM concept in process industry. The limitation of this research is it was done only in the clove leaf oil derivative. Research in more aromatic chemical derivatives is needed.

\section{Refferences}

Abdulmalek, F. A., Rajgopal, J., \&Needy, K. L. (2006). A Classification Scheme for the Process Industry to Guide the Implementation of Lean. Engineering Management Journal, 18(2), 15.

Alves, A. C., Carvalho, J. D., \&Sousa, R. M. (2012). Lean production as promoter of thinkers to achieve $\begin{array}{lllll}\text { companies' agility. The learning } & \text { Organization, } 213-237 .\end{array}$ http://dx.doi.org/10.1108/09696471211219930

Angelis, J., Conti, R., Cooper, C., \& Gill, C. (2011). Building a high-commitment lean culture. Journal of Manufacturing Technology Management, 22(5), 569-586. http://dx.doi.org/10.1108/17410381111134446 
Ben-Tovim, D. I., Bassham, J. E., Bolch, D., Martin, M. A., Dougherty, M., \& Szwarcbord, M. (2007). Lean thinking across a hospital : redesigning care at the Flinders Medical Centre. Australian Health Review, $31(1), 10$.

Bhasin, S. (2012). An appropriate strategy for lean success. Management Decision, 50(3), 439-458. http://dx.doi.org/10.1108/00251741211216223

Brosnahan, J. P. (2008). Unleash the power of lean accounting. Journal of Accounting, 206(1), 60.

Chauhan, G., \& Singh, T. P. (2012). Measuring parameters of lean manufacturing realization. Measuring Bussines Excellence, 16(3), 57-71. http://dx.doi.org/10.1108/13683041211257411

Chen, L., \& Meng, B. (2010). The application of value stream mapping based lean production system. International Journal of Business and Management, 5(6).

Coronado, M., Adrian, E. L., \& Andrew, C. (2007). Evaluating operations flexibility in industrial supply chains to support build-to-order initiatives. Business Process Management Journal, 13(4). http://dx.doi.org/10.1108/14637150710763586

Donatelli, A. J., \& Harris, G. A. (2001). Combining Value Stream Mapping and Discrete Event Simulation. Proceedings of the Huntsville Simulation Conference. San Diego, CA: By the Society for Modeling and Simulation International.

Forrester, P. L., Shimizu, U. K., Soriano-Meier, H., Garza-Reyes, J. A., \& Basso, L. F. C. (2010). Lean production, market share and value creation in the agricultural machinery sector in Brazil. Journal of Manufacturing Technology Management, 21(7), 853-871. http://dx.doi.org/10.1108/17410381011077955

Fullerton, R. R., \& Wempe, W. F. (2009). Lean manufacturing, non financial performance measures, and financial performance. International Journal of Operations \& Production Management, 29(3), 214-240. http://dx.doi.org/10.1108/01443570910938970

Gahagan, S. M. (2007). Adding Value to Value Stream Mapping: A simulation Model Template for VSM. Proceedings of 2007 Industrial Engineering Research Conference.

Guiterrez, R. S., Barajas, H., Galaviz, M. E., \& Martinez, L. C. (2003). An Application of Value Stream Mapping in International Logistics System. IIE Annual Conference.Proceedings: 1-4.

Hines, P., \& Rich, N. (1997). The Seven value stream mapping tools. International Journal of Operations \& Production Management, 17(1), 46-64.

Hines, P., Rich, N., \& Hittmeyer, M. (1998). Competing against ignorance: Advantage through knowledge. International Journal of Physical Distribution \& Logistics Management, 28(1), 18-43.

Indonesian Ministry of Industry. (2009). Regulation of Industry Ministry of Republic of Indonesia Number 136/M-IND/PER/IO/2009 about Road Map Cluster Development of Essential Oil Industry. Jakarta, Indonesia.

Keogh, M. K. (2006). Reducing value stream lead time: a two phase analysis of the factors contribute to the success of manufacturing streamlining initiatives [dissertation]. USA: Capella University. UMI Number 3226810 .

Lander, E. (2007). Implementing Toyota-Style Systems in High Variability Environments [dissertation]. USA: University of Michigan. UMI Microform 3257511.

Lasa, I. S., Laburu, C. O., \&Vila, R. C. (2008). An evaluation of the value stream mapping tool. Business Process Management Journal, 14(1), 39-52. http://dx.doi.org/10.1108/14637150810849391

Lewis, M. A. (2000).Lean production and sustainable competitive advantage.International Journal of Operations \& Production Management, 20(8), 959-978.

McManus, H. L., \&Millard, R. L. (2002). Value Stream Analysis and Mapping for Product Development.The International Council of the Aeronautical Sciences. Massachusetts Institute of Technology.

Miina, A., Saat, M., \& Kolbre, E. (2013). Critical success factors of lean thinking implementation in Estonian manufacturing companies. Baltic Journal of Economics, 13(1), 109-120.

Olsen, E. O. (2004). Lean manufacturing management: the relationship between practice and firm level financial performance [dissertation]. USA: The Ohio State University. UMI Number 3148201. 
Rahman, S., Laosirihongthong, T., \& Sohal, A. S. (2010).Impact of lean strategy on operational performance: a study of Thail manufacturing companies. Journal of Maufacturing Technology Management, 21(7), 839-852.

Rathi, N., \& Farris, J. A. (2010). Evaluating the Applicability of Lean Manufacturing in Process Industries. In A. Johnson, \& J. Miller (Eds.), Proceedings of the 2010 Industrial Engineering Research Conference.

Rother, M., \& Shook, J. (2003). Learning too see: Value stream mapping to add value and eliminate muda. Version 1.3. Brookline: The Lean Enterprise Institute.

Seth, D., Seth, N., \& Goel, D. (2008). Application of value stream mapping (VSM) for minimization of wastes in the processing side of supply chain of cottonseed oil industry in Indian context. Journal of Manufacturing Technology Management, 19(4). http://dx.doi.org/10.1108/17410380810869950

Shah, R. (2002). A configurational view of lean manufacturing and its theoretical implications [dissertation]. USA: The Ohio State University. UMI Number 3059319.

Shen, S. X., \& Han, C. F. (2006). China electrical manufacturing services industry value stream mapping collaboration. Int. J. Flex. Manuf Syst., 18, 285-303. http://dx.doi.org/10.1007/s10696-007-9016-6

Simons, D., \& Keivan, Z. (2005). Application of lean paradigm in red meat processing. Bristish Food Journal, 107(4/5), 192-211.

Singh, B., \& Sharma, S. K. (2009). Value stream mapping as a versatile tool for lean implementation: an Indian case study of a manufacturing firm. Measuring Business Excellence, 13(3), 58-68. http://10.1108/13683040910984338

Singh, B., Garg, S. K., \& Sharma, S.K. (2010). Lean implementation and its benefits to production industry.International Journal of Lean Six Sigma, 1(2), 157-168. http://dx.doi.org/10.1108/20401461011049520

Singh, H., \& Singh, A. (2013). Apllication of lean manufacturing using value stream mapping in an auto-parts manufacturing unit. Journal of Advances in Management Research, 10(1), 72-84. http://10.1108/09727981311327776

Solding, P., \& Gullander, P. (2009). Concepts for Simulation Based Value Stream Mapping. Proceedings of the 2009 Winter Simulation Conference.

Sun, S. (2011). The strategic role of lean production in SOE's development.International Journal of Bussines and Management, 6(2).

Upadhye, N., Deshmukh, S. G., \& Garg, S. (2010). Lean manufacturing for sustainable development. Global Bussines \& management research: An International Journal, 2(1), 125-137.

Vinodh, S., Arvind, K. R., \& Somanaathan, M. (2011). Tools and techniques for enabling sustainability through lean initiatives. Clean Techn Environ Policy, 13, 469-479. http://dx.doi.org/10.1007/s10098-010-0329-x

Watson, J. L. Jr. (2006). Integrating lean manufacturing with technology: analyzing the effects on organizational performance in terms of quality, cost and response time [dissertation]. USA: Capella University. UMI Number: 3226218

Wee, H. M., \& Wu, S. (2009). Lean supply chain and its effect on product cost and quality: a case study on Ford Motor Company. Supply chain management: An international Journal, 14(5), 335-341. http://dx.doi.org/10.1108/13598540910980242

Woehrle, S. L., \& Abou-Shady, L. (2010). Using dynamic value stream mapping and lean accounting box scores to support lean implementation. American Journal of Business Education, 3(8).

Woll, C. A. (2003). Identifying value in Instructional Production System: Mapping the value stream [dissertation]. USA: Utah State University. UMI Number: 3095309

\section{Copyrights}

Copyright for this articleis retained by the author(s), with first publication rights granted to the journal.

This is an open-access article distributed under the terms and conditions of the CreativeCommons Attribution license (http://creativecommons.org/licenses/by/3.0/). 